Тетяна СУКАЛЕНКО,

orcid.org/0000-0002-5107-9914

доктор філологічних наук,

професор кафедри журналістики, украӥнської словесності та культури

Університету державної фіскальної служби України

(Ірпінь, Київська область, Україна) sukalenko78@gmail.com

Наталія ЛАДИНЯК, orcid.org/0000-0002-5107-9914 кандидат філологічних наук, доиент кафедри української мови

Кам'янеиь-Подільського національного університету імені Івана Огієнка (Кам'янець-Подільський, Хмельницька область, Украӥна) ladyniakn@gmail.com

\title{
СЛУЖБОВЕ ЛИСТУВАННЯ ЯК ФОРМА СУЧАСНОЇ ДІЛОВОЇ КОМУНІКАЦЇ̈
}

Стаття присвячена вивченню службового листування як формі ділової комунікації. Об'єктом аналізу є особливості службових листів як різновиду ділових документів, їхні функиії, основні вимоги до укладання, специфіка електронного листування. Визначено, щчо службові листи становлять найпоширеніший різновид ділових документів, за допомогою яких встановлюються відносини між фізичними та юридичними особами, компаніями, організаціями, регулюються дипломатичні стосунки між державами. Проаналізовано погляди науковців на службовий лист як різновид ділового листа. Описано структуру сучасного ділового листа, охарактеризовано його функиії, встановлено особливості вживання мовних засобів. Визначено специфіку електронних службових листах. До переваг електронного листування віднесено динамічність, ивидкість здіснення ділової комунікації, можливість встановлення однобічного зв'язку, коли листи надсилаються незнайомим адресатам за наявності їхної електронної адреси. Наголошено, щьо уміння укладати документи є важливим для фахівия будь-якої галузі. Це визначено робочими навчальними програмами дисциплін для здобувачів вищої освіти: "Службове та дипломатичне листування (практикум)» (спеціальність «Міжнародне право»), "Ділова украӥнська мова», «Украӥнська мова (за професійним спілкуванням)» (усі спеціальності). Мета їх вивчення - засвоєння теоретичних знань та вироблення практичних навичок здійснення письмової ділової комунікації із застосуванням різних форм і видів роботи: аналізу текстів ділових листів, визначення їхніх структурних та мовних особливостей, стилістичного редагування, укладання зразків службових листів відповідно до різних комунікативних ситуачій. Визначено перспективи подальших наукових студій із проблем службового листування.

Ключові слова: службове листування, службовий лист, ділова комунікаџія, ділова кореспонденція, електронний службовий лист.

Tetiana SUKALENKO, orcid.org/0000-0002-5107-9914 Doctor of Philological Sciences, Professor at the Department of Journalism, Ukrainian Philology and Culture Department University of the State Fiscal Service of Ukraine (Irpin, Kyiv region, Ukraine) sukalenko78@gmail.com

Nataliia LADYNIAK, orcid.org/0000-0002-3091-0772

Candidate of Philological Sciences, Associate Professor at the Department of Ukrainian Philology and Journalism Kamianets-Podilskyi Ivan Ohiienko National University (Kamianets-Podilskyi, Khmelnytskyi region,Ukraine) ladyniakn@gmail.com

\section{OFFICIAL CORRESPONDENCE AS A FORM OF MODERN BUSINESS COMMUNICATION}

The article deals with the study of business correspondence as a form of business communication. The object of the analysis are the features of business letters as a type of business documents, their functions, the basic requirements for writing, the specifics of electronic correspondence. It is found out that official letters are the most common type of business documents, which establish relations between individuals and legal entities, companies, organizations; regulate diplomatic 
relations between states. Researchers'views on the official letter as a type of business letter are analyzed. The structure of the modern business letter is described, its functions are characterized, and features of use of language means are established. The specifics of electronic business letters are determined. The advantages of e-mail include dynamism, speed of business communication, and the ability to establish one-way communication, when emails are sent to unknown recipients if their e-mail address is known. It is emphasized that the ability to conclude documents is important for a specialist in any field. This is determined by the curricula of disciplines for applicants for higher education: "Official and diplomatic correspondence (practicum)" (specialty "International Law"), "Business Ukrainian", "Ukrainian language (for professional communication)" (all specialties). The purpose of their study is to acquire theoretical knowledge and develop practical skills of written business communication using different forms and types of work: analysis of texts of business letters, determining their structural and linguistic features, stylistic editing, compiling samples of business letters according to different communicative situations. The perspectives for further studies on the problems of business correspondence are identified.

Key words: official correspondence, business letter, business communication, business correspondence, electronic business letter.

Постановка проблеми. Успіх сучасного фахівця будь-якої галузі значною мірою залежить не лише від обсягу знань, навичок професійної діяльності, досвіду, а й від його вміння висловлювати думки правильно, чітко, зрозуміло, привертати увагу співрозмовника, переконливо виступати під час ділових зустрічей, укладати відповідно до вимог документи.

Ділові відносини між роботодавцем і працівником, установами, організаціями, угоди між підприємствами, державами традиційно відбиті в документах. Високий рівень офіційності ділової комунікації вимагає дотримання особливих вимог до складання документів у певній галузі. Під час укладання документів із кадрово-контрактних питань, довідково-інформаційних та ін. учасникам ділової комунікації необхідно знати вимоги щодо змісту, структури, особливості уживання мовних засобів і дотримуватися їх. У дипломатичній галузі вміння складати документи відповідно до міжнародних стандартів $є$ винятково важливим, оскільки в них представлено зовнішньополітичні інтереси держави.

Сучасним засобом ділової комунікації є службове листування, своєрідне «спілкування в мініатюрі» між установою та особою, установами й організаціями або різними країнами, що має свої жанри, структуру, засоби тощо. Воно допомагає встановити відносини 3 діловими партнерами, забезпечити високий рівень ефективності діяльності підприємства, установи, організації, успішно реалізовувати зовнішньополітичні інтереси держави, сприяти добросусідським стосункам між країнами. Успішне вирішення важливих питань значною мірою зумовлене якістю, точністю, грамотністю укладених документів.

Аналіз досліджень. Службове листування неодноразово ставало об'єктом дослідження мовознавців. Зокрема, Т. А. Крисанова розглянула лексико-граматичні особливості англійського та українського ділового листа: компаративний аспект, I. Є. Шаргай визначила комунікативнопрагматичні особливості французького ділового листа в оригіналі та перекладі, А. Л. Котковець проаналізувала композиційну структуру мовленнєвого жанру «діловий лист», О. М. Попова, Ю. В. Кабанчук дослідили особливості написання ділових листів у Великобританії та Україні: порівняльний аналіз, М. А. Чепурна охарактеризувала особливості перекладу ділових листів та ін С. В. Шевчук уклала довідник зі службового листування, у якому подано класифікацію до листів, вимоги до оформлення. О. Н. Ель-Амарі ділове листування визначає як «текстову комунікацію, якій властиві дистантність та опосередкованість, письмова форма і монологічністю, міжособистісна контактність та офіційність, стереотипізація й наративність, кооперативність і конфліктність, інформативність та фатична настанова» (Эль-Амари, 2018: 52).

Тлумачення понять «службовий лист» і «діловий лист» у сучасній лінгвістиці близькі, подекуди їх ототожнюють. С. В. Шевчук визначає лист (діловий) як «поширений вид документації, один із способів обміну інформацією» (Шевчук, 2004: 255). Службові листи вважає основним засобом встановлення офіційних, службових контактів, мета яких «пояснити, переконати, поінформувати і спонукати адресата до певної дії» (Шевчук, 2004: 255). I. М. Плотницька тлумачить службовий лист як «документ, за допомогою якого відбувається письмове спілкування між установами, організаціями й особами» (Плотницька, 2011: 80). На думку О. В. Коновченко, ділові листи - «листи, що стосуються економічної, правової, фінансової та інших форм діяльності підприємства. Вони вирішують організаційні питання, питання економічних відносин і правових проблем» (Коновченко, 2012: 6).

Предметом нашого розгляду є службове листування як форма сучасної ділової комунікації, що представлена різними типами листів, має особливості залежно від галузі, у якій реалізується. 
Мета статті - охарактеризувати особливості службових листів як різновиду ділових документів, визначити їхні функції, основні вимоги до укладання, розкрити специфіку електронного листування.

Виклад основного матеріалу. Службове листування в українському діловому просторі має давню традицію, яка пов'язана 3 розвитком листування в Україні та світі загалом. Як зазначають Л. І. Мацько, О. М. Сидоренко, О. М. Мацько, початки історії листування варто «шукати ще в епоху виникнення письма, і пройшло воно багато етапів (перекази, грамоти, послання...), поки набуло форми листів, яким властива і своя композиція тексту, і специфічні мовні засоби» (Мацько, Л., Сидоренко, Мацько, О., 2003: 296).

Розвиток службового листування в Україні свої витоками сягає ще часів Київської Русі, коли 3'явилися перші зразки писемного ділового спілкування: княжі устави, грамоти, угоди тощо. Однак тоді листи ще не мали чітко окреслених ознак, притаманних сучасним діловим документам.

В епоху Просвітництва науковці, філософи проводили дискусії у формі листування (згадаймо листи Феофана Прокоповича, Григорія Сковороди та ін.). У цей час укладалися «письмовники» «збірники листів і послань на всі випадки життя» (Мацько, Л., Сидоренко, Мацько, О., 2003: 296). Ïх автори прагнули виробити певні мовні стандарти, які б допомагали надати змістові листа належної форми. Лист поступово набував обов'язкових елементів - це формули вітання, звертання, встановлення контакту, висловлення поваги, прихильності, прохання й прощання. Згодом деякі 3 них стали традиційними етикетними формулами i були відтворені в ділових листах.

Особливостями сучасних службових листів $€$ різноманітність їхніх видів, чітка структурованість, уживання типових зворотів, стилістичних мовних засобів. Службові листи виконують низку важливих функцій: інформаційну, що полягає у повідомленні фактів, відомостей; організаційну, яка координує діяльність організацій; юридичну лист є офіційним документом, який має чинність під час розгляду спірних питань у відносинах сторін ділової комунікації тощо. Листу притаманні інформативність, об'єктивність, цілісність, зв'язність, завершеність, стандартизованість, комунікативна спрямованість.

Цілком погоджуємося 3 думкою багатьох дослідників, які наголошують на тому, що письмова комунікація $\epsilon$ зазвичай підготовленою. «Навіть якщо адресант вимагає термінової відповіді, адресат має змогу спочатку продумати зміст майбутнього тексту листа, підготувати його з погляду мовної організації, а потім вже скласти готове мовне повідомлення» (ЭльАмари, 2018: 53-54). Учасниками письмової комунікації є дві сторони - адресат та адресант. Вона реалізується в такій послідовності: формування мотиву комунікації, який полягає в потребі надіслати або інформацію, бажанні впливати на учасників ділового спілкування; встановлення контакту; визначення мети; оцінювання ситуації та партнера ділової комунікації; обмірковування попереднього плану листа; добір коректних мовних засобів; написання тексту листа; встановлення зворотного зв'язку.

Офіційне листування передбачає реалізацію конкретної мети, дотримання певної структури, стилістики, однозначності змісту. Під час написання службових листів варто дотримуватися таких основних вимог: 1) писати чітко, зрозуміло, стисло; 2) розміщувати реквізити листа відповідно до встановлених правил; 3) дотримуватися визначеної побудови зворотів, прямого порядку слів; 4) уникати значної кількості прикметників, надмірності займенників (у листах від першої особи), надавати перевагу дієслівним формам на -но, -то; 5) уживати етикетні формули.

Для службового листування властива уніфікованість мовних конструкцій, або кліше, які дають змогу адресантові оперативно складати лист, допомагають адресатові правильно сприймати текст. У службових листах уживають типові мовні

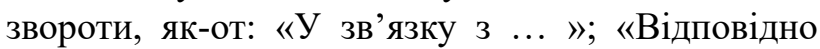
до...»; «3 метою...», «Вважаємо за потрібне...», «Повідомляємо, що...», «Просимо Вас звернути особливу увагу...».

Сучасний службовий лист набуває нових рис, оскільки виник додатковий спосіб його представлення - електронний, що відкриває більші можливості для встановлення зв'язків між різними учасниками ділової комунікації, незважаючи на їхню просторову віддаленість одне від одного. Електронний службовий лист надсилається на електронну пошту адресата - окремої особи, підприємства, установи. Його перевагами $є$ швидкість надсилання інформації та одержання відповіді, можливість здійснити розсилку на різні електронні скриньки. Як різновид ділового листа електронний службовий лист має ознаки, подібні до паперового: чітку структуру, уживання офіційних етикетних формул (звертання, прощання й ін.), типових граматичних конструкцій, відповідне функційне призначення. Вирізняльними його рисами є динамічність, лаконічність, уживання спеціальних форм. 
Загалом структуру електронного службового листа можна подати послідовним переліком таких реквізитів: адресат, адресант, дата, час надсилання, текст листа, підпис із зазначенням контактних даних, кількість вкладень до листа. Назву листа рекомендовано подавати в рядку «Тема», наприкінці розміщувати підпис. Зручним є автопідпис, що може містити посаду та прізвище особи, назву установи, юридичну адресу, номер телефону та адресу електронної пошти, які автоматично з'являються наприкінці кожного листа. У разі надсилання двох та більше файлів-додатків потрібно повідомляти про це адресата.

Доречно під час написання службових листів скористатися такими порадами:

1. Укладаючи лист, варто бути лаконічним, подавати важливу інформацію чітко, змістовно, уникаючи зайвих коментарів, відступів, пояснень.

2. Викладати думки логічно й послідовно, заздалегідь добре їх обміркувавши.

3. Уникати багатозначності, надмірного вживання слів іншомовного походження.

4. Бути ввічливим, уживати етикетні формули звертання, привітання, вибачення, подяки, попередження тощо.

5. Бути доброзичливим, уникати вживання слів та зворотів з відтінком категоричності: «Вимагаємо негайно..», «Категорично забороняємо...», «Цілковито не погоджуємося...»та ін., варто замінювати їх більш коректними формулами.

Фахівці в галузі ділового листування рекомендують іноді вдаватися до використання гумору та «магічних слів», що надасть листуванню виразності та емоційності «живого» ділового спілкування, сприятиме встановленню контактів між учасниками комунікації (Універсальний практикум, 1997: 306).

Уміння укладати документи $є$ важливим для фахівця будь-якої галузі. Це також визначено робочими навчальними програмами дисциплін для здобувачів вищої освіти: «Службове та дипломатичне листування (практикум)», (спеціальність «Міжнародне право»), «Ділова українська мова», «Українська мова (за професійним спілкуванням)» (усі спеціальності). На заняттях студенти засвоюють поняття про службовий лист, види листів, основні вимоги до їх укладання тощо. Вироблення практичних навичок здійснюється із застосуванням: різних форм і видів роботи: аналізу текстів ділових листів, визначення їхніх структурних та мовних особливостей, стилістичного редагування, укладання зразків службових листів відповідно до різних комунікативних ситуацій.

Висновки. Службове листування є засобом комунікації між установами, організаціями, підприємствами, приватними та юридичними особами. За допомогою листування здійснюється обмін важливою інформацією, забезпечуються заходи різного рівня. Від якості, точності, грамотності укладених службових листів залежить успіх вирішення важливих питань. Службові листи мають чітку структуру, послідовність викладу, стандартизовані мовні конструкції, етикетні формули. Електронне листування набуває все більшого поширення як різновид ділового спілкування завдяки динамічності, швидкості надсилання й отримання офіційної інформації. Навчальні дисципліни «Службове та дипломатичне листування (практикум)», «Ділова українська мова», «Українська мова (за професійним спілкуванням)» дають змогу сформувати у здобувачів вищої освіти вміння й навички укладати документи службового листування відповідно відповідно до різних комунікативних ситуацій та визначених завдань. Перспективи подальших досліджень вбачаємо у встановленні традицій укладання службових листів різними мовами, особливостей здіснення офіційного листування між організаціями, установами України та інших держав.

\section{СПИСОК ВИКОРИСТАНИХ ДЖЕРЕЛ}

1. Коновченко О. В. Міжнародне листування : навч. посіб. Харків : Нац. аерокосм. ун-т ім. М. Є. Жуковського «XAI», 2012.98 c.

2. Мацько Л. І., Сидоренко О. М., Мацько О. М. Стилістика української мови : підручник. Київ : Вища школа, 2003. $462 \mathrm{c}$.

3. Плотницька І. М. Ділова українська мова в державному управлінні : навч. посіб. Київ : НАДУ, 2011. 168 с.

4. Універсальний довідник-практикум з ділових паперів / С. П. Бибик, І. Л. Михно, Л. О. Пустовіт, Г. М. Сюта. Київ : Довіра : УНВЦ «Рідна мова». 1997. 399 с.

5. Шевчук С. В. Ділове мовлення для державних службовців : навч. посібник. Київ : Літера ЛТД, 2004. 400 с.

6. Эль-Амари О. Н. Деловое письмо как жанр современной письменной коммуникации на русском языке : дисс. ... кандидата филол. наук : специальность 10.02.01 «Русский язык». Ярославль, 2018. 304 с. 


\section{REFRENCES}

1. El-Amari O. N. Delovoye pismo kak zhanr sovremennoy pismennoy kommunikatsii na russkom yazyke. [Business letter as a genre of modern written communication in Russian] : dissert. ... kandidata filol. nauk : spetsialnost 10.02 .01 «Russkiy yazyk». Yaroslavl, 2018. 304 p. [In Russian].

2. Konovchenko O. V. Mizhnarodne lystuvannia [International correspondence] : navchalnyi posibnyk. Kharkiv : Natsionalnyi aerokosmichnyi universytet im. M. Y. Zhukovskoho «Kharkivskyi Natsionalnyi Universytet», 2012. 98 p. [In Ukranian].

3. Matsko L. I., Sydorenko O. M Matsko O. M. Stylistyka ukraiinskoii movy. [Stylistics of the Ukrainian language]. Kyiiv : Vyshcha shkola, 2003. 462 p. [In Ukranian].

4. Plotnytska I. M. Dilova ukraiinska mova v derzhavnomu upravlinni. [Business Ukrainian language in public administration] : navchalnyi posibnyk. Kyiv : NADU, 2011. 168 p. [In Ukranian].

5. Shevchuk S.V. Dilove movlennia dlia derzhavnykh sluzhbovtsiv. [Business speech for civil servants] : navchalnyi posibnyk. Kyiv : Litera LTD, 2004. 400 p.

6. Universalnyi dovidnyk-praktykum z dilovykh paperiv [Universal guide-workshop on business papers] / S. P. Bybyk, I. L. Mykhno, L. O. Pustovit, H. M. Siuta.: Kyiv : UNVT «Ridna mova», 1997. 399 p. [In Ukranian]. 